\title{
The Geological - Mining and Geotechnical Opinion as a Supplement to the Geotechnical Documentation in a Region of the Past Underground Mining
}

\author{
Rafał Jendruś , Dr. Eng.* **,Paweł Wrona, Dr. Eng.*, Michał Mazurek, \\ Dr. Eng.*, Anna Manowska, Dr. Eng.* \\ *Silesian University of Technology, Faculty of Mining and Geology, Akademicka 2A, 44-100 Gliwice, Poland, \\ www.polsl.pl \\ **Geotechnical Services Company ,,GeoRock”, Armii Krajowej 14/I/10, 41-943 Piekary Slaskie, Poland, \\ www.georock.pl
}

\begin{abstract}
The purpose of a geological-mining report and geotechnical opinion, is to provide information about historical mining operations undertaken in the site of future construction works together with the assessment of potential geotechnical risk for the planned building or structure from the point of the view of post-mining influences. Preparing of such a report should be required by the building designers and construction engineers, especially in the case when the subsidence and ground conditions are not determined and predictable enough for reliable design of foundations and other critical parameters. The authors discuss the problem of mining influences and ground conditions on buildings and ground infrastructure construction. They give the example of application of expertise algorithm on the basis of a case study from the city of Tarnowskie Gory in the southern part of Poland. The example refers to modernisation of the road and technical infrastructure on the Repecka Street, located in the area of historical mining operations. Sinkhole subsidence risk in the investigated site is the additional aspect and it is connected with the presence of soluble limestone formation under shallow loose quaternary sands. It represents geological configuration highly vulnerable for surface sinkholes.
\end{abstract}

Key words: geotechnical reporting, post-mining areas, mining influences

\section{Introduction}

The regulation of the Polish Ministry of Transport, Construction and Maritime Economy, from 25th April 2012, on the establishment of the geotechnical conditions for the foundations of buildings (Polish Government Journal of Law No. 81, item. 463) is the legal basis for the application and content of geotechnical documentations in Poland. It obligates investors to obtain geotechnical reports (expertises) for the all geotechnical categories of site-specific grounds, which may impose influences for prospective buildings and structures. The main objective of such a geotechnical report, in terms of Polish regulations, is to determine the geotechnical category of the building construction, dependently to the complexity of existing ground conditions. In the case of more complex ground conditions, detailed geological-engineering report, and geological-mining report may be required. The procedure relates to all building and infrastructure projects located in the areas of current mining operations, however, the presence of historical mining should be considered as a reason for preparation of the geological-mining report, too.

Shallow mine voids (abandoned underground workings and cavings, which did not subside under small pressure of the overburden strata) cause discontinuous deformations at the surface of the ground, which can be dangerous for the use of land and create environmental hazard, as well as hazard for public safety. Investigated site, which is discussed in this paper, is located in southern part of Poland, in the area of occurrence of large silver, lead, and zinc ores deposit, which were subject of mine activities since Middle Ages up to the beginning of XX century [7].

The area of the city of Tarnowskie Gory, located directly above the relatively shallow ore body (Triassic carbonates roof is present here at a depth of round $25 \mathrm{~m}$ ) is particularly exposed to the risk of discontinuous deformations (it has been included to the highest sinkhole occurrence risk), which may occur as the result of reactivation of cavities remaining after mining operations in the ore body with zinc, lead and silver sulphide ore deposits. There is a variety of existing factors which can impact on the emergence of discontinuous surface deformation. Therefore, sinkholes appearance is difficult to assess.

The schema of obligatory procedure path between the investment and the start of construction works is shown in Figure 1.

Accordingly to the law, geotechnical conditions can be divided into three categories: simple, complex, and complicated conditions. 
a) Simple conditions - the ground is homogenous, level of underground water is lower than the level of future object foundation, insufficient geological phenomena are not observed.

b) Complex conditions - the ground is heterogeneous, level of underground water is higher or on the same level as level of future foundation, although insufficient geological phenomena are not observed.

c) Complicated conditions - the same factors like in b) and insufficient geological phenomena are observed (e.g. karst phenomena, the influence of underground mining works etc.).

In each case, elaboration of a geotechnical report is necessary, however, its content will be the most complex in the case $c$ ).

In the case a) if the investment is planned within a mining area, only the investor itself decides about the necessity of the mining - geological report elaboration. In the case b), an investor, to fulfil the legal requirements, must include following documents into project documentation: geotechnical report, ground subsoil documentation, geotechnical design, and in the case of a mining area - mining-geological report.

In the case of c), an investor must collect: geotechnical report, geological work design, mining works schedule, ground subsoil documentation, geological - engineering documentation, geotechnical design and finally mining - geological report.

\section{Location of the construction site}

The considered area is located in southern part of Poland, at the north part of The Upper Silesia Coal Basin, at the surface of well historically known metal ore body under the city of Tarnowskie Gory. Repecka Street connects two districts of the city, and reflects the historical route of traffic. The road was a connection between two villages: Old Repty and Stare Tarnowice, which currently belong to the city of Tarnowskie Gory. Scope of the prospective works covers reconstruction and adaptation of the road infrastructure to the current needs of heavy traffic and transport. Repecka Street is forming the eastern border of a Natural Park created in the 19th century around the non- existing today palace, with a total surface of 18.8 ha. Repecka Street in its central part runs through not urbanised terrains (green areas, parks and agricultural fields), however, in its initial and final parts it runs through residential areas of the districts of Stare Repty and Stare Tarnowice (Fig. 2). Underground tourist object called the Black Trout Drift is located in the area of a natural garden. It consists of two shafts and the drifts (Frederick's drainage drifts), which gravitationally drain water from still existing underground workings to the rivers flowing in valleys in some distance from the historical ore mining area.

\section{Geological structure}

The city of Tarnowskie Gory is located on the hill of so - called Tarnogorski Hump formed by limestones and dolomites, which belong to the shell limestone ridge covered by thin layer of Quaternary sediments. In the northern part of The Upper Silesian industrial area, Triassic limestone formations contain sulphide zinc, lead and silver ore deposits, mostly nowadays industrially depleted. Different ore minerals usually do not occur together; rather they create local aggregations of different mineral composition. In Tarnowskie Gory the area of metal ore is represented mainly by galenite (lead glance). As the sulphide ores they are never homogeneous. Lead in this ore body is accompanied by silver $(0,1-1,2 \%)$ and small amounts of other elements. The most valuable silver ores were the aim of the oldest mine operations in the area.

Geological profile is dominated by the Silesian Triassic strata (Fig. 3), which lay inconsistently on different Paleozoic sediments, mainly Devonian and Carboniferous [4, 9].

The presence of limestone rocks, which are subject of intensive chemical erosion by percolating waters, allows creating of different forms of karst phenomena. Karst sinkholes in the Triassic roof can reach diameter of $50-100 \mathrm{~m}$ and up to $10 \mathrm{~m}$ in depth. Drainage of Triassic bedrock, which must be maintained in aim to protect underground museum sites established in the area, increases the intensity of karst processes and may result in creation of cavings and finally - cover collapse or subsidence sinkholes [4].

\section{The history of ore mining in the area of Tarnowskie Gory}

Mining in the area of Tarnowskie Gory dates back to the early Middle Ages and makes this area one of the oldest centres of metal ore mining in Europe. The oldest recorded information about ore mining in this region comes from the year 1136 and refer to the extraction of silver. The document signed by the Prince Wladyslaw from Opole in the year 1247 gives information about ore mining in the area of Repty Slaskie, which nowadays is a part of the city of Tarnowskie Gory. Mining works near Tarnowskie Gory were being conducted continuously since the early Middle Ages up to the year 1912, when finally decision for abandoning of the mines have been taken due to exhaustion of the ore body by the German mining and geological authorities. They administrated the area until the year 1920 (That is the reason, why the source maps have been prepared by the German, not Polish authorities).

Today, the area of historical mine operations in Tarnowskie Gory includes $185 \mathrm{~km}$ of preserved underground workings in a form of galleries, caverns, adits, and a huge amount of the remnants of historic 
extraction works, mainly in the form of shallow shafts and galleries, in a various state of preservation. The total number of these shafts is estimated to be around 20000 [2].

From the geotechnical point of the view, to the remnants of historical mining operations belong also the anthropogenically formed land structures resulted from the open pit mining (meadow iron ore was subject of scattered extraction in these region), waste dumping, and landfilling.

\section{Mining methods and their influence on the current geotechnical conditions of the ground surface}

Lead and silver ore deposit in the area of Tarnowskie Gory are represented by the thin, irregular nests and veins, located within the Triassic formation of limestone and dolomite, and covered with relatively thin (up to about $30 \mathrm{~m}$ ) layers of Quaternary sands and topsoil [9]. Lack of major tectonic disturbances, and the small depth of the Triassic bedrock result in stability of mining workings, which exist intact for hundreds of years.

From the other side, it is important to note that the limestone undergoes karstification processes, what means that voids of significant sizes may be created due to natural processes, which may be later filled up with water, quicksand or loose rocks. A threat of flooding was the main obstacle for mining activities in the area of Tarnowskie Gory, due to coincidence of natural and mine voids in an highly permeable rock mass environment.

Due to the elevation of the area, gravitational drainage of the ore body was possible by driving long drifts from the ore body to the water courses located away from the mining area [8].

In the early stages of development of mining operations in the area of Tarnowskie Gory simple shafts were driven into the deposit as both exploration and access workings. From these shafts, short and narrow horizontal galleries were driven, tracing the veins of ore. Length of these galleries was limited mainly by the conditions of natural ventilation offered by single shaft access. Gradually, a system of single shaft entries had transformed into a complex system of underground workings with limited number of shafts, however, as a legacy of these early days of mining, there are exist remnants of round twenty thousands of these shafts with their surroundings. It must be kept in mind that in the past, mining structures were likely abandoned than liquidated after the end of their use (mine closure is a relatively modern issue). The historical shafts are filled up with Quaternary loose rocks from the thin subsurface layers [2, 5].

When a larger aggregation of ore-bearing minerals was found, a gallery was extended to a room of a size limited by the stability of the roof, with occasional use of timber packs and artificial pillars made from the waste rock. After longer time, such rooms often became unstable and collapsed, what resulted in cover collapse sinkholes and increased potential of the bedrock for further deformation processes.

Galleries of small dimensions, being driven in limestone or dolomitic formations are able to remain even hundreds of years and the risk of their collapsing could be negligible, if water influence might be ignored. Chemical erosion of carbonates by percolating waters enables creation of caverns and channels (i.e. by expanding of thin fractures created in results of collapse of large rooms or caves), and finally leads to create hydraulic connections between overlaying strata and existing old workings, which may be rapidly flooded by large volume of a mixture of water and loose grounds, what results in creation of a sinkhole on the surface. Such a phenomena occurred frequently in the undermined areas of Tarnowskie Gory.

\section{6. Analysis of historical maps of ore operation in the region of Tarnowskie Gory}

In 1912 the former Mining Authority (originally "Oberbergamt") in Wroclaw published an atlas of geological maps in a scale of 1: 5000, which depicted very precisely ore deposits and mine development in the area of Upper Silesia [1]. In the case of Tarnowskie Gory, due to the abandonment of mining works in the following year, the presented state can be considered as the final state of mining extraction. The location of the Repecka Street in Tarnowskie Gory on a map of historical mining of metal ores (Sheet nr 6 Stare Tarnowice and sheet nr 10 Repty), was determined on the basis of the still existing roads and other objects, which are compatible with the map view from the beginning of the $20^{\text {th }}$ century. The shape of Repecka Street in Tarnowskie Gory was marked in Fig.4 and 5.

From the analysis of the maps, it may be concluded that Repecka Street is not lying close to areas of mining activities. Accordingly to the maps, the nearest shafts are located in the distance of about 500 metres towards the East and West from. These shafts, called skylights (originally "Lichtlöcher") were made for ventilation and enlightening purposes for the drainage drift (Frederick's drift), which is running across Repecka Street.

A dotted black line in the Figures 4 and 5 shows approximately the western border of the dolomitic metal ore deposit in Tarnowskie Gory, which runs almost parallel to Repecka Street in a distance of about 500 $\mathrm{m}$.

The only mining objects nearby the road are three small shafts (skylights) numbered as III and IV on Figures 4, 5, and 6. in the area of currently existing Natural Park and the Frederick's drift; depth of the drift is 
round $55 \mathrm{~m}$ below the surface. Profile of the Frederick's drift has been presented on the Fig. 6 . The drift still collects water percolating from the surface to the bedrock with a daily output of $50.000 \mathrm{~m}^{3}$ [8]. Nowadays, there is a possibility to take a boat trip through the drift between shafts (skylights) II and III, what belongs to the main local tourist attractions. Presence of water in the drift indicates that the working keeps its conductivity and has not been collapsed nor filled up with the quicksand.

Already collected experience from the considered area lead to a general observation that in the proximity of historical mine sites increases probability of the occurrence of anthropogenically reformed grounds - landfills, remnants of open pits, spoil heaps etc. Presence of such structures is often not documented cartographically and is to be determined in a result of exploration drillings conducted during geotechnical research at the ground preparation stage of a building construction or civil engineering works.

However, due to the fact that the route, which is currently named Repecka Street, exists for at least 100 years (and probably the route is much older), it can be assumed that the foundation of the road does not contain any artificially introduced rocks or waste, which could decrease geotechnical properties of the grounds under the road.

The only potentially existing risk for the stability of the foundation in the route of the Repecka Street relates to the erosion of limestone and subsidence of loose overburden strata. Both processes are managed by precipitation and include suffosion, advective migration of mineral grains, or even liquefaction of sandy formations (quicksand), where the intensity of flow of ground water is determined by the drainage of limestone bedrock by the drifts $\left(50.000 \mathrm{~m}^{3}\right.$ of water per day is collected by the Frederick's drift, and there are also other operational drifts exists in the whole area of Tarnowskie Gory mining area [8]).

The risk of sinkholes occurrence due to erosive influence of ground waters on the Quaternary (mainly suffusion) and Triassic formations (mainly karstification) may be considered as natural phenomena, resulted from the physical-chemical properties of carbonates rocks and alluvial sediments, being indirectly powered by mining interference in the rock mass.

Mentioned analysis indicates that accordingly to the scheme (Figure 1), future investment belongs to the category a. The location is not exactly within the mining area, however decision about the necessity of elaboration of a mining - geological report should be undertaken by the investor.

\section{Geotechnical research}

The aim of the research is:

- the acquisition of data referred to soil layers location,

- the assessment of geotechnical parameters of the layers,

- the acquisition of data referred to water system and permeability of the strata in considered area (especially due to changes caused by anthropogenic factors - mainly old mining activities),

Considered area (one part of Repecka street) is designed for house construction works.

Two small diameter boreholes at the depth 4,0m (the sum equals 8 linear meters) for examination into water system and soil conditions. Macroscopic examinations and observation of water system were conducted during drilling (fig.7).

\subsection{Water system}

During drilling at the depth $4,0 \mathrm{~m}$ and conducted observation it was stated that there is no underground water. Therefore water system for future investment is proper.

Considering permeability it was found that the ground is heterogeneous. Obtained results can be divided into following groups:

- $\quad$ permeable, being represented by fine sand having approximated filtration coefficient $k=10^{-4}$ $10^{-5}[\mathrm{~m} / \mathrm{s}]$,

- strongly permeable, being represented by medium grained sand having approximated filtration coefficient $\mathrm{k}=10^{-3}-10^{-4}[\mathrm{~m} / \mathrm{s}]$,

weakly permeable being represented by loamy sand with gravel having approximated filtration coefficient $\mathrm{k}=10^{-5}-10^{-6}[\mathrm{~m} / \mathrm{s}]$,

semi-permeable being represented by loam having approximated filtration coefficient $\mathrm{k}=10^{-6}$ $-10^{-7}[\mathrm{~m} / \mathrm{s}]$

\subsection{Soil conditions}

Conducted examinations gave the information that the subsoil is present in the base of considered area. There are following geotechnical layers (with different physical and mechanical parameters): 
Layer Ia1 cohesionless subsoil being represented by fine sand. They are moist, medium compacted with average rate of compaction $I_{\text {D }}=\mathbf{0 , 5 0}$.

Layer Ia2 cohesionless subsoil being represented by middle grained sand and loamy sand and gravel. They are moist, medium compacted with average rate of compaction $I_{D}=0,50$.

Layer Ib1 cohesionless soil, unconsolidated. Considering lithology they are built of loam and loamy sand with gravel. The consistence is stiff with plasticity index $I_{L}=0,20$.

Layer Ib2 cohesionless soil, unconsolidated being represented by loam. The consistence is, $\mathbf{I}_{\mathbf{L}}=\mathbf{0 , 3 0}$. (fig.9).

Supplementary information is given in documentation sheets (fig.8) and in geological cross-section

\subsection{Analysis}

Basing on conducted field tests and research it can be stated that in the base of examined area - under the layer of unequally compressible ground (layer I with depth of $0,4 \mathrm{~m}-1,3 \mathrm{~m}$ ) - there is low compactable and heaving bearing capacity. They are represented by middle compacted types of sand and gravel mix (layers IIa1IIa3, fig.9).

Groundwater has not been detected until the depth of 4,0m.

Accordingly to the results of the tests (noticed conditions) designed house can be constructed without any objections at subsoil of layers IIa1-IIa3. However, some problems can be met during soilwork. It is connected with made grounds and their workability (old house foundations). In the area of future road and the house, there are made grounds of non-swelling soil, being expansive type.

Therefore, soilwork should be conducted accordingly to PN-B-06050 Geotechnika. Roboty ziemne. Wymagania ogólne.

Considering the type of the object (linear and point) and noticed conditions (for ground and water) II geotechnical category (with simple ground conditions) is proposed for the investment.

However, accordingly to the proper Polish Regulation of the Polish Ministry of Transport, Construction and Maritime Economy, from 25th April 2012, on the establishment of the geotechnical conditions for the foundations of buildings (Polish Government Journal of Law No. 81, item. 463) is the legal basis for the application and content of geotechnical documentations in Poland final decision due to geotechnical category is undertaken by a designer.

\section{Conclusion}

No traces of mining operations have been found in the area of investigation, which could create high risks for the stability of the foundation of a road and public safety issues.

Historical drainage drift, which runs transversely to the course of the Repecka Street at the depth of about $55 \mathrm{~m}$ will not pose a risk for the surfaces structures, and vice versa, modernisation of the road should not pose risk of damage to the historical underground object.

Probability of occurrence of anthropogenically disturbed rocks and grounds in the shallow strata below the course of the road is minimal; however presence of waste or other weakened grounds may be definitely determined during geotechnical research on the site.

Collapse and subsidence sinkholes may occur on the area of investigation, while the geological structure of the rock mass is dominated by thick limestone bedrock covered by relatively thin layer of unconsolidated formations: soils, sands, gravels, and clay. Drainage of waters from the area of historical mining workings increases significantly mobility of percolating waters. Vulnerability of considered area on occurrence of deformations resulted from appearance of solution cavities (karst) may be determined by research on archival reports about road surface (pavement) failures and repair works in the course of Repecka Street in the records of the local municipal services.

Engineering practice in area of Upper Silesia Coal Basin shows that building and construction investors frequently underestimate a fact that their construction site are located on a mining or post-mining area, and often overlook issues related to the mining activities, which took place more than - let's say - more than 10 years ago.

The present danger from the side of earlier or even historical mining operations can exist, in advantageous conditions, even hundreds after abandoning of a mine.

Changes in stability conditions, like increased loadings on the foundation layers, dynamic loadings and vibrations resulted from heavy machinery and structures operation on a site during construction or use of an object may trigger off processes in the shallow rock mass strata, generally considered as the activation of voids, which result in sinkholes or other other forms of mine subsidence.

Geological-mining reports reveal information, which can be easily overlooked during typical geotechnical investigation of a building construction site. Even if analysis of mining and geological items of 
considered area does not provide directly measurable factors for design engineers, its objective is to focus the attention of interested investment parties on potential geotechnical risks, what shall result in adoption of appropriate protective measures into the project, or at least into commission of a detailed geotechnical research, which range will reflect the conclusions from the geological-mining reports.

\section{References}

[1] Erzkarte des Oberbergamt in Breslau (ore map of the Head Mining Authority in Breslau), published in Berlin In 1912, sheet number 6 - Stare Tarnowice (Alt Tarnowittz) and 10 - Repty (Repten), scale 1: 10000

[2] Gad P., Rosenbaum S.: Tarnowskie Góry - podziemia (Tarnowskie Gory - the undergrounds . ISBN: 978-83-61458-71-9, Tarnowskie Góry, 2010

[3] http://www.wikimapia.org - hybrid view of the selected area of Repecka street

[4] http://www.geoturystyka.ovh.org/geoturystyka/dolomity.html

[5] Jendruś R., Strozik G.: Ekspertyza geologiczno-górnicza dla potrzeb rozbudowy odcinka ulicy Repeckiej w Tarnowskich Górach wraz infrastrukturą i przebudową zjazdów. (Geological-mining report for development of Repecka Street in Tarnowskie Gory with infrastructure and reconstruction of junctions), Technical Company Georock, Piekary Śląskie 2012 (not published)

[6] Jendruś R., Strozik G.: Ekspertyza geologiczno-górnicza dla potrzeb hali sportowej przy ulicy Obwodnicowej w Tarnowskich Górach (Geological-mining report for Sport Arena At Obwodnicowa Street in Tarnowskie Gory). Technical Company Georock, Piekary Śląskie 2012 (not published)

[7] Kotyrba A., Tyrała A., Michalak J.: Płytka eksploatacja złóż węgla kamiennego i rud cynkowo-ołowiowych oraz metody eliminacji jej wpływu na warunki geologiczno-inżynierskie województwa katowickiego Shallow coal and zinc-lead ore mining and methods of elimination of its influence on the geological-enginneering conditions on the Katowice region). Prace Naukowe Głównego Instytutu Górnictwa 1998, s. Konferencje, nr 24 8. Kozłowski S.: Surowce skalne Polski. Wydawnictwo Geologiczne, Warszawa 1986

[8] Grodecki W., Madryas C., Tajduś A., Tokarr A., Wichur A., Żylińsk R.:Wybrane problemy budownictwa podziemnego, Górnictwo i Geoinżynieria nr 29, Zeszyt 3/1, 2005

[9] Moszny J.: Rola i znaczenie sztolni odwadniających w górnictwie tarnogórskim (Role and importance of drainage drifts in Th miting At Tarnowskie Gory). Materiały Sympozjum 45 lat działalności Sztolni Czarnego Pstrąga w Tarnowskich Górach. Stowarzyszenie miłośników Ziemi Tarnogórskiej, Tarnowskie Góry, 2003, ISBN 83-904063-5-7. (www.podziemia.pl/doc/tt2/b1-2cie1.html)

[10] Marschalko M. Yilmaz I., Lamich D., Bednárik M.: Underground mining hazard map including building site categories in an area affected by underground mining activities, Environmental Earth Sciences, no 03, 2014

[11] Medhurst T. Hatherly P. Hoyer D.: Investigation of the relationship between strata characteristics and longwall caving behaviour, Conference Paper - Coal Operators' Conference, 2014

[12] Villaescusa E.: Geotechnical Design for Sublevel Open Stoping, CRC Press, 2014

[13] Szulc J., 2008. Trias obszaru śląsko-krakowskiego (Triassic formations in the region of Silesia and Crackow). Materiały 42. Sympozjum Speleologicznego Tarnowskie Góry, 24-26.10.2008.

\section{Figures}

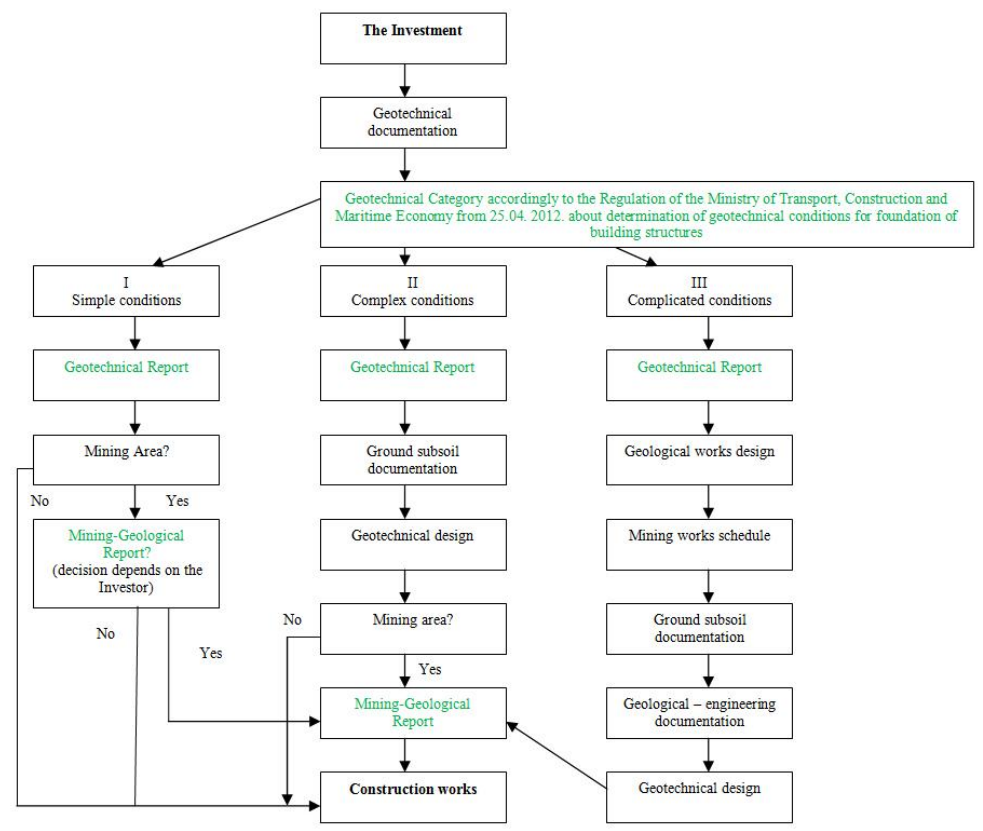

Fig. 1. The scheme of geotechnical proceedings with respect to presence of and residues of earlier and currently running mining works 


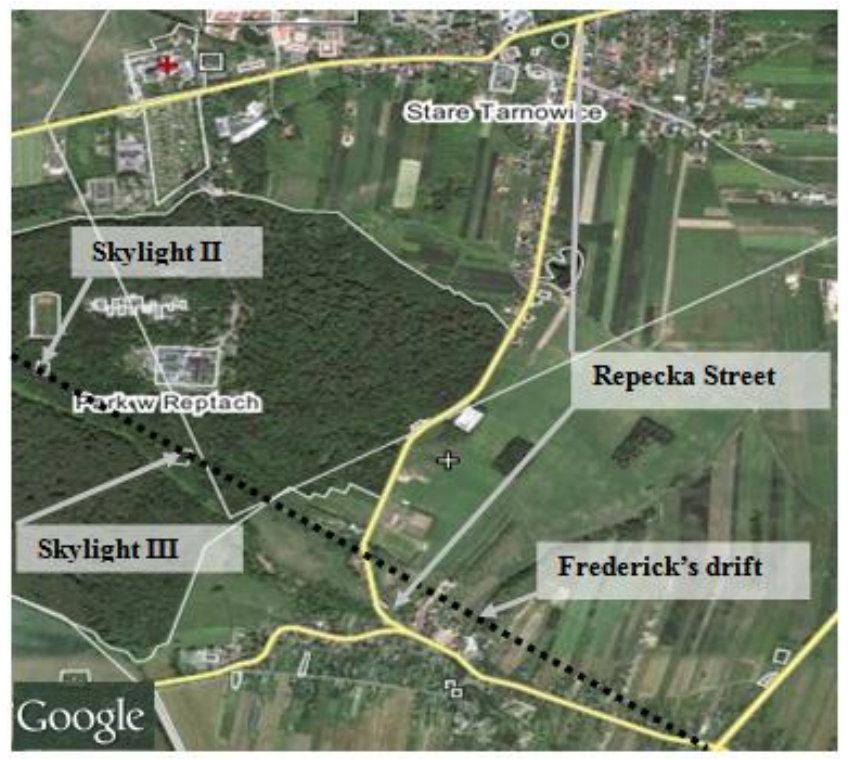

Fig. 2. Surface view of the Repecka Street in Tarnowskie Gory with the localisation of the main mining objects mentioned in the text [3]

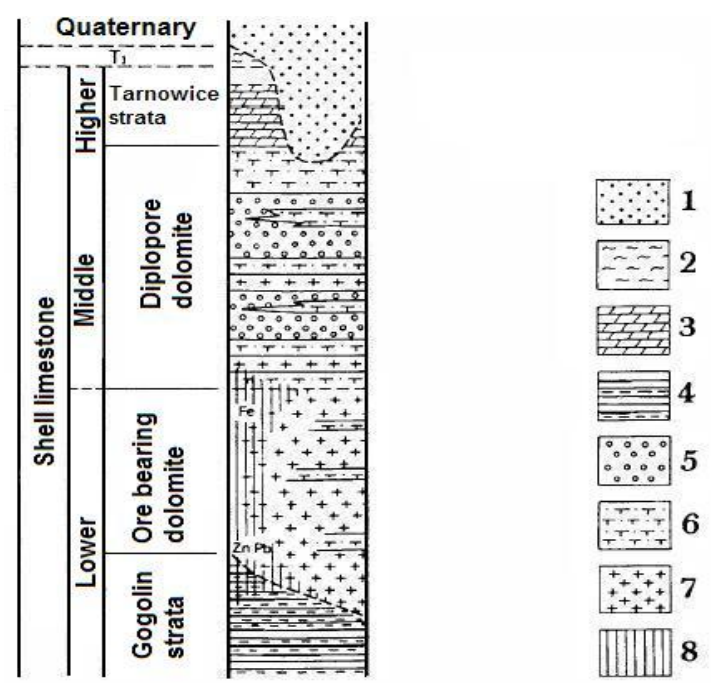

Fig. 3.The sequence of limestone deposits in the area of investigation [4].

1 - Clay, sand and gra e', 2 - Clay, 3 - marlaceous dolomite, 4 - limestone, marlaceous limestone, and marlite, 5 -oolitic dolomite, 6 - grainy dolomite, 7 - crystal dolomites, 8 - increased mineralization

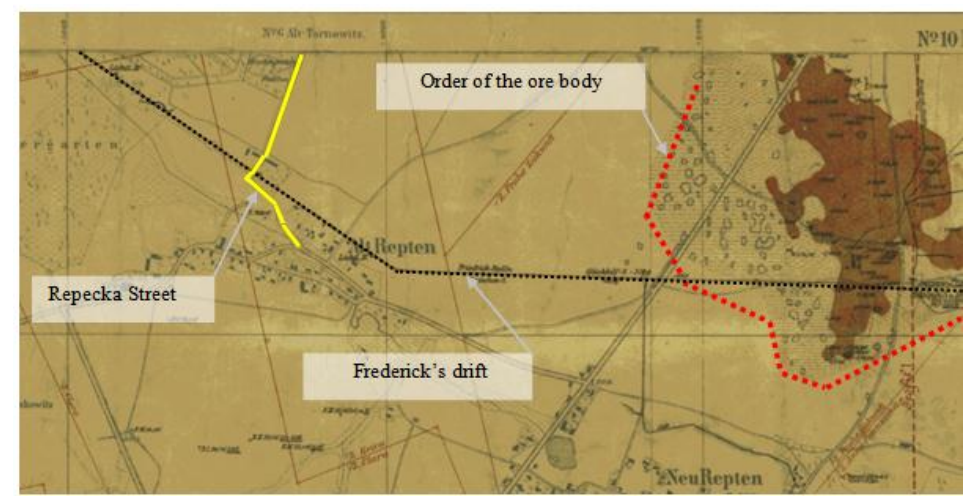

Fig.4. Southern part of the Repecka Street with the border of the ore body and course of the drainage drift (Frederick's drift) [1] 


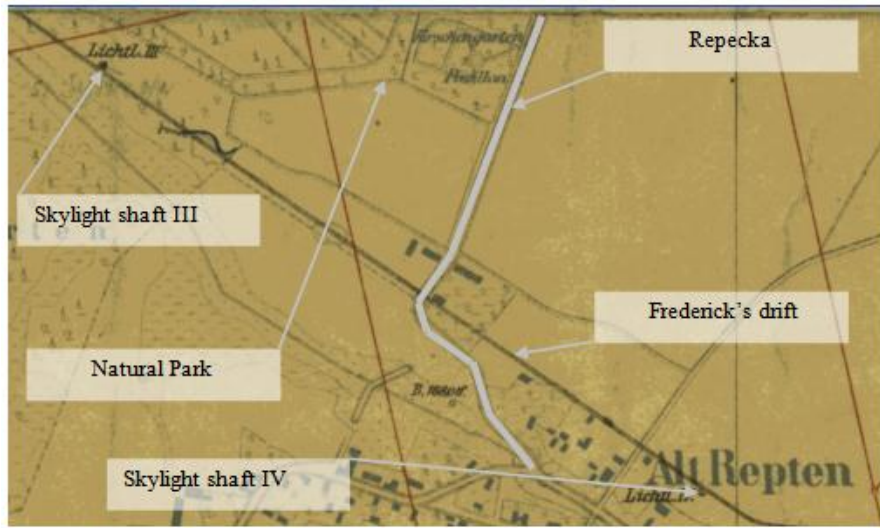

Fig.5. Enlarged fragment of the map from Fig. 3. [1]

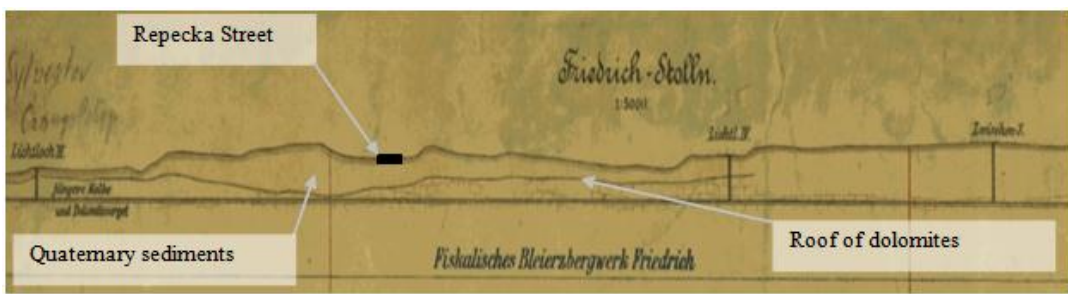

Fig.6. Cross section of the Frederick's drainage drift with the position of the roof of Triassic limestone formation and Quaternary sediments of variable thickness [1]

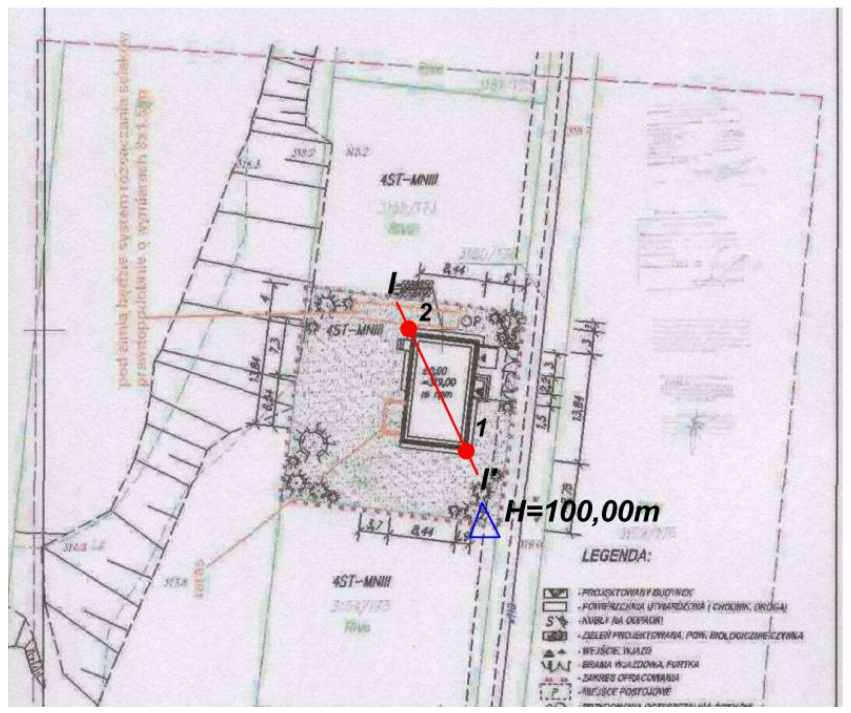

Fig.7. The schema of future investment. Location of examination boreholes, [5].

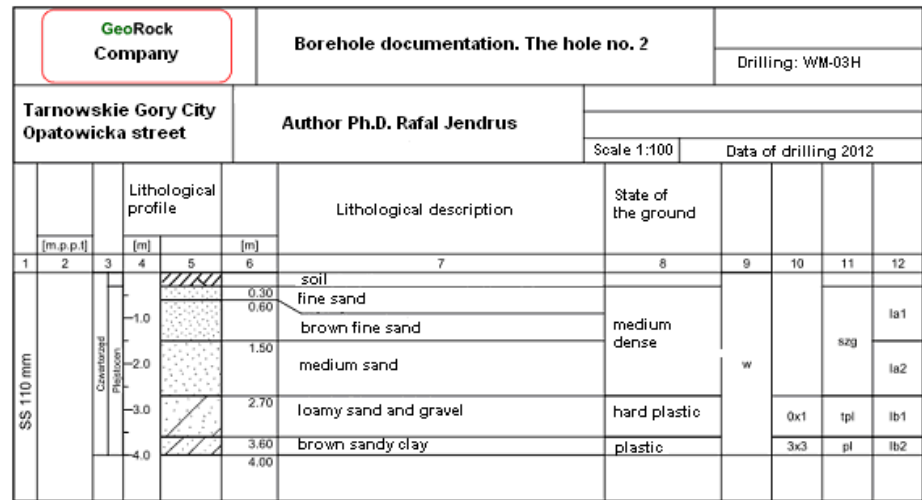

Fig.8. The example of borehole documentation. The hole no. 2, [5]. 


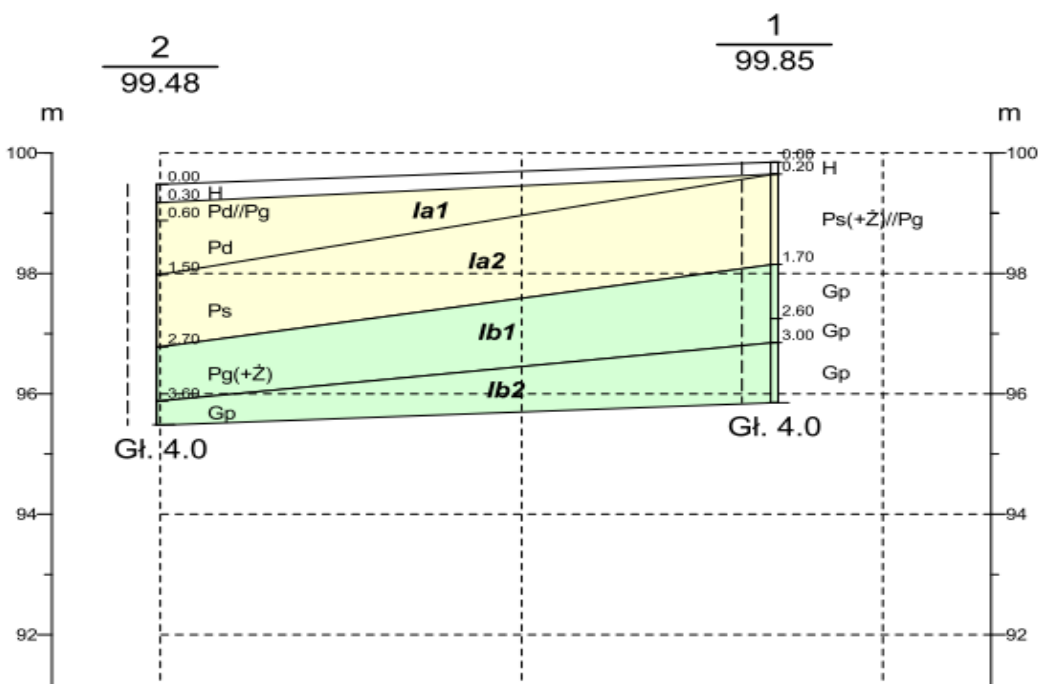

Fig.9. Geological cross-section, the holes no. 1 and 2, [5]. 